\title{
CONGENITAL PANCREATIC LIPASE DEFICIENCY
}

\author{
BY \\ WILFRID SHELDON \\ From The Hospital for Sick Children, Great Ormond Street, London
}

(RECEIVED FOR PUBLICATION SEPTEMBER 30, 1963)

The purpose of this communication is to record two families, each consisting of two children. The four children have presented an identical clinical picture associated with a congenital severe reduction of pancreatic lipase, and have responded to persistent treatment with lipase given as pancreatin. A brief reference was made to Case 1 in the Charles West Lecture, delivered before the Royal College of Physicians of London in 1955 (Sheldon, 1955).

The families are not related to each other. The parents are not consanguineous, and both are healthy.

Also recorded is a fifth case, concerning a child who experienced a temporary reduction of pancreatic lipase production following varicella.

\section{Case Reports}

\section{Family A}

Case 1. C.D., a boy, born in March 1950, birth weight $7 \mathrm{lb} .11 \mathrm{oz}$. (3486 g.). First attended hospital at $2 \frac{1}{2}$ years of age, with a history described by his family doctor in the following terms: 'He has always had very peculiar greasy stools. The greasy part of the stools is always yellow or orange in colour and tends to separate from the rest of the motion. It floats on water; solidifies like flakes on cold water or like drops of oil on hot water. It tends to seep through his clothes. His bowel habit is regular, one or two motions daily. His development is normal for his age.' The odour of the stools was seldom offensive.

On examination, the boy weighed $30 \mathrm{lb} .(13.6 \mathrm{~kg}$.) (normal). There were no abnormal physical signs, and the abdomen was not noticeably distended.

Analysis of the duodenal juice is shown in the Table. Other investigations revealed the following: haemoglobin $90 \%$; glucose tolerance test normal: after $18 \mathrm{~g}$. glucose the fasting blood sugar rose from $82 \mathrm{mg}$. to a maximum of $141 \mathrm{mg} . / 100 \mathrm{ml}$. in half an hour. Stools contained no pathogenic organisms, cysts or ova. Fat absorption (10-day balance) $68 \%$, and under treatment with pancreatin (8-day balance) it rose to $78 \%$. Sweat electrolytes (1956) normal. $\mathrm{Na} 37.5 \mathrm{mEq} / \mathrm{l}$ : $\mathrm{Cl} 36$ $\mathrm{mEq} / \mathrm{l}$;; $\mathrm{K} 6 \mathrm{mEq} / \mathrm{l}$.

Chylomicron counts are shown in Fig. 1, where it can be seen that the original flat curve before treatment was improved by pancreatin, although the curve was still well below normal. A meal of emulsified fat, kindly supplied by Professor A. C. Frazer, gave a normal response, indicating that the capacity to absorb fat was unimpaired provided that emulsification could take place.

A test was also carried out when the boy was at home to ascertain whether bile salts would be of value. The test was arranged in three fortnightly periods. In the first, the boy was given $1 \mathrm{~g}$. bile salts daily, without pancreatin. During this period he passed 33 stools, with oil separating out in 32 of them. In the second, he was given the same dose of bile salts together with pancreatin $5 \mathrm{~g}$. with each meal. During this period he passed 19 stools, with oil separating out in 11. In the third period bile salts were omitted, but the pancreatin continued. During this period he passed 18 stools, with oil separating out in 6 . It was concluded that while pancreatin was beneficial, bile salts were without effect. The test is mentioned because of its simplicity.

A duodenal juice analysis was repeated at 5 years of age (Table).

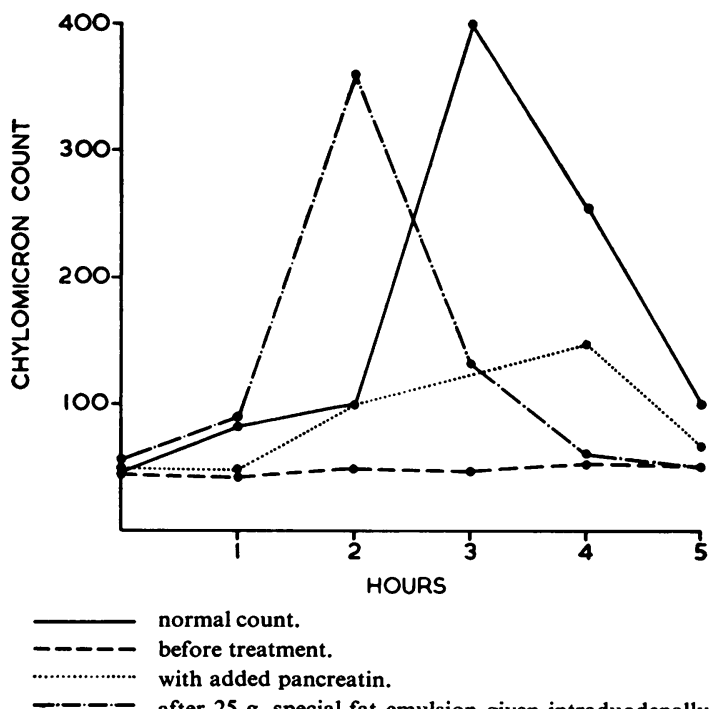

after 25 g. special fat emulsion given intraduodenally.

Fig. 1.-Chylomicron counts from Case 1. 
TABLE

ANALYSIS OF DUODENAL JUICES

\begin{tabular}{|c|c|c|c|c|c|c|}
\hline Case No. & $\begin{array}{l}\text { Age } \\
\text { (yr.) }\end{array}$ & $\begin{array}{c}\text { Lipase } \\
\text { Normal > } 20 \text { units }\end{array}$ & $\begin{array}{l}\text { Trypsin } \\
\text { Normal: Complete Gelatin Digestion } \\
\text { (C.G.D.) at Dilution of Duodenal } \\
\text { Juice 1:200 }\end{array}$ & $\begin{array}{l}\text { Amylase } \\
\text { Normal Range Somogyi } \\
\text { units (S.U.): } 500-1500\end{array}$ & Bile Salts & $\begin{array}{c}\text { Fat } \\
\text { Absorption } \\
(\%)\end{array}$ \\
\hline 1 & $\begin{array}{c}11^{\frac{3}{2}} \\
5\end{array}$ & $\begin{array}{l}\text { Nil } \\
\text { Nil }\end{array}$ & $\begin{array}{l}\text { C.G.D. } 1: 50 \\
\text { C.G.D. } 1: 100\end{array}$ & $\begin{array}{l}\text { Complete digestion of } \\
\text { starch at dilution } 1: 2 \\
\text { duodenal juice* }\end{array}$ & & 68 \\
\hline 2 & $1 \frac{5}{12}$ & 2.9 units & C.G.D. $1: 100$ & & & \\
\hline 3 & 6 6 & $\begin{array}{l}<1 \text { unit } \\
2 \text { units }\end{array}$ & $\begin{array}{l}\text { C.G.D. } 1: 1600 \\
\text { C.G.D. } 1: 800\end{array}$ & $\begin{array}{l}333 \text { S.U.t } \\
155 \text { S.U.t }\end{array}$ & $\begin{array}{l}\text { Present } \\
\text { Present }\end{array}$ & 70 \\
\hline 4 & 2 & $\begin{array}{l}5 \cdot 3 \text { units } \\
11 \text { units }\end{array}$ & $\begin{array}{l}\text { C.G.D. } 1: 200 \\
\text { C.G.D. } 1: 50\end{array}$ & 360 S.U.‡ & Present & 70 \\
\hline 5 & $6_{\frac{1}{2}}^{\frac{9}{2}}$ & $\begin{array}{l}3.9 \text { units } \\
1 \text { unit }\end{array}$ & $\begin{array}{l}\text { C.G.D. } 1: 800 \\
\text { C.G.D. } 1: 12 \cdot 5\end{array}$ & $\begin{array}{l}470 \text { S.U.† } \\
1260 \text { S.U. }+\end{array}$ & Present & 61 \\
\hline
\end{tabular}

Lipase was estimated from a method adapted from that of Shwachman, Farber and Maddock (1943); trypsin, from a method of Horsfield (1952) amylase, in three ways: * Wohlegemuth's method, see Harrison (1957); † adapted from method of Van Loon, Likins and Seger (1952) and $\ddagger$ adapted from method of Young (1953).

He is now $13 \frac{1}{2}$ years of age, and is very healthy and intelligent. His height at 62.5 in. $(158 \mathrm{~cm}$.) is at the 70th percentile, and his weight at $87 \mathrm{lb} .(39.5 \mathrm{~kg}$.) is at the 25th percentile. In spite of persistent therapy with pancreatin ( $5 \mathrm{~g}$. with each meal), he occasionally soils his clothes with liquid oil unless his dietary fat is carefully controlled. His mother has learned just how much fat she can allow him. He invariably soils if a dose of pancreatin is omitted.

Case 2. S.D., a girl, was born in September 1957, birth weight $8 \mathrm{lb} .12 \mathrm{oz}$. (3960 g.); by 2 months of age the stools were noted to be pale, at 4 months their surface glistened, and by 9 months a little free oil was separating from them. Although the child was thriving quite well, the mother had no doubt that she was suffering in the same way as her brother. At 16 months she was soiling her clothing with liquid oil.

She was admitted to hospital at 17 months for examination of her duodenal juice. The analysis is shown in the Table. Examination showed her to be a healthy thriving infant. The abdomen was not distended. The stools, apart from being oily, were slightly offensive. A fingerprint sweat test showed no excess of electrolytes.

Since then treatment with pancreatin has been continuous, the dose having been gradually increased to the present level of $5 \mathrm{~g}$. with each meal. The child is thriving well, and now at 5 years 10 months, her height at $46 \cdot 5$ in. $(118 \mathrm{~cm}$.) is at the 75 th percentile, and her weight at $47 \mathrm{lb}$. $(21.3 \mathrm{~kg}$.) is also at the 75 th percentile. She still occasionally soils her clothes with oil.

\section{Family B}

Case 3. T.O'B., a boy, born in January 1956, birth weight $7 \mathrm{lb} .14 \mathrm{oz}$. (3571 g.), since birth had passed up to four bulky offensive motions daily, with droplets of fat separating out on their surface, which solidified on standing. Greasy soiling of his clothes occurred frequently. Despite this, his appetite had been good and his general health satisfactory, although he is smaller than average. In this last respect he takes after his parents. Between 3 and 4 years of age he was given a gluten-free diet without appreciable benefit.

He was admitted to Great Ormond Street at 5 years and 10 months of age. A lively active boy, he had no abnormal physical signs; the abdomen was not distended. Two analyses of his duodenal juice are shown in the Table. Other investigations revealed, a haemoglobin of $96 \%$; bone age equivalent to $4 \frac{1}{2}$ years; glucose tolerance test: after $18 \mathrm{~g}$. glucose the fasting blood sugar rose from $83 \mathrm{mg}$. to a maximum of $110 \mathrm{mg} . / 100 \mathrm{ml}$. after 90 minutes. Sweat electrolytes normal: $\mathrm{Na} 34 \mathrm{mEq} / 1 .: \mathrm{Cl} 26 \mathrm{mEq} / \mathrm{l}$; $\mathrm{K} 15 \mathrm{mEq} / \mathrm{l}$. Total serum proteins $6.9 \mathrm{~g} . / 100 \mathrm{ml}$. ? Electrophoretic pattern normal. Serum folic acid normal. FIGLU test negative. Stools contained no pathogenic organisms, cysts or ova.

Fat absorption on normal diet (six day balance) $70 \%$; on a gluten-free diet (six-day balance) $82 \%$; and on a normal diet with oral pancreatin (six-day balance) $82 \%$.

Treatment has consisted of a normal diet with pancreatin, $5 \mathrm{~g}$. with each meal, since $6 \frac{1}{2}$ years. On this régime the boy has remained well: his stools have averaged one daily and have appeared normal. His mother has to control the amount of fatty food that he eats: a recent meal of ice-cream and cheese led to an oily stool with soiling of his garments.

Now at $7 \frac{1}{2}$ years the boy's height at $46.5 \mathrm{in} .(118 \mathrm{~cm}$.) is on the 10th percentile, and his weight at $47 \mathrm{lb} .(21 \mathrm{~kg}$.) is on the 12th percentile.

Case 4. F.O'B., a boy, born in September 1960, birth weight $7 \mathrm{lb}$. (3175 g.) is said always to have passed bulky pale offensive stools, up to four daily, which his mother described as containing 'melted butter'. He was admitted to Great Ormond Street at 2 years of age, when he appeared well nourished, albeit a small boy. There were no abnormal physical signs, and the abdomen was not distended.

Two analyses of the duodenal juice are shown in the Table. Other investigations included haemoglobin $82 \%$; 
glucose tolerance test normal: the fasting blood sugar rose from $86 \mathrm{mg}$. to $154 \mathrm{mg} . / 100 \mathrm{ml}$. in one hour. Sweat electrolytes normal: $\mathrm{Na} 44 \mathrm{mEq} / \mathrm{l}$; $\mathrm{Cl} 57 \mathrm{mEq} / \mathrm{l}$; K $13 \mathrm{mEq} / \mathrm{l}$. The stools contained cysts of Giardia lamblia (treated with mepacrine). Fat absorption on normal diet (six-day balance) $70 \%$.

Since 2 years of age (i.e. for 12 months) the child has been treated with increasing doses of pancreatin, but with little benefit until the dose was worked up to $4 \mathrm{~g}$. with each meal: at that level free oil has ceased to appear in the stools. He continues to grow steadily, but remains small for his age. At 3 years, his height at 34 in. $(86 \cdot 3 \mathrm{~cm}$.) is on the 3 rd percentile, and his weight at $27 \cdot 5 \mathrm{lb} .(12 \cdot 5 \mathrm{~kg}$.) is on the 10th percentile.

\section{Comments on Cases 1-4}

In 1943 Farber, Shwachman and Maddock reported a boy whose duodenal juice showed a selective deficiency of trypsin, although lipase and amylase were present in normal amounts. This was regarded as a congenital and permanent defect. In 1951, Lowe and May recorded a 13-year-old boy whose duodenal juice showed a persistent absence of amylase and much reduced trypsin, but a normal amount of lipase. This was regarded as a primary absence of amylase with, in addition, deficiency of trypsin.

As far as the author is aware, cases with demonstrable deficiency of lipase comparable to those reported in this communication have not been previously recorded. In all four cases the disorder was congenital. The deficiency of lipase was severe, indeed in the first case it was completely absent. It is considered that this deficiency accounted for the unusual and typical appearance of the stools from which oil separated out.

The production of trypsin was also reduced, with the exception of Case 3 , and this may have contributed to the offensive odour of the stools through degradation of protein in the gut. The production of amylase was also below the normal range, but was presumably sufficient to prevent excessive intestinal fermentation of carbohydrate and consequent abdominal distension.

The clinical story and findings on examination were remarkably constant in all four of the children. From early in infancy a greasy oily quality to the stools was noticed, and sooner or later there was a story of liquid oil separating from the motions, the oil solidifying as the motion cooled. When most children are gaining control of their bowel movements, these children were handicapped by soiling their clothes with liquid oil which they were unable to restrain. This history, common to all the children, combined with satisfactory thriving and lack of abdominal distension, at once distinguished them from other causes of steatorrhoea in childhood.
The character of the stools was quite unlike that met with in fibrocystic disease of the pancreas, or in coeliac disease, which together account for the great majority of children who exhibit steatorrhoea. Other clinical distinctions from fibrocystic disease of the pancreas lay in the satisfactory growth, the less severe malodour of the stools, the lack of abdominal distension, and the absence of respiratory infections leading to lung damage. Further distinction by laboratory methods was afforded by the normal electrolyte content of the sweat and the analytical data from the duodenal juice.

Clinical distinction from coeliac disease lay in the early onset, the steady growth, the good appetite, the lack of abdominal distension, the good muscle tone, and the absence of anaemia. None of the children showed the flat glucose tolerance curve so usual in untreated coeliac disease.

The peculiar quality of the stools and the satisfactory growth serve, in the author's opinion, to separate these children from those with the rare condition of congenital deficiency of the exocrine pancreas which has been recently reviewed by Bodian, Sheldon and Lightwood (1964).

It is of interest that in spite of a greatly diminished production of pancreatic lipase, fat absorption in the three cases in which this investigation was undertaken was as high as $68 \%, 70 \%$, and $70 \%$, due maybe in part to the action of lipase derived from the stomach and intestine. Although treatment with pancreatin improved fat absorption and brought the oily condition of the stools and the soiling under control, it did not restore fat absorption to normal. Dietary control of fat intake remained necessary, any excess leading to a return of oil in the stools and soiling.

The fact that both children of each family suffered from the complaint suggests an inherited factor. Dr. Cedric Carter, of the Clinical Genetics Unit at Great Ormond Street, kindly investigated this aspect. He was unable to trace any consanguinity between the parents, or to find any link between the two families, and concluded that the condition was very probably due to an autosomal recessive gene.

\section{Case 5}

B.L., a boy, whose parents and a younger sister are healthy, was born in August 1953. He had been healthy and lively until, at the age of $6 \frac{1}{4}$ years, immediately following upon an attack of varicella, he began a persistent fatty diarrhoea. He also soiled himself with oil: the mother's description was 'as though he had sat in a patch of oil'. The stools numbered up to six daily; they were pale, slightly offensive and oily. The oil set hard and yellow on standing. The appetite remained good, there was no abdominal pain or vomiting, and there had been no loss of weight. 
On admission to Great Ormond Street at the age of $6 \frac{3}{4}$ years, the boy appeared healthy and well nourished. The abdomen was not distended. The results of analysis of the duodenal juice on admission, and again three months later, are shown in the Table. Other investigations revealed a haemoglobin of $77 \%$; the glucose tolerance test was normal: the blood sugar rose from a fasting level of $110 \mathrm{mg}$. to $198 \mathrm{mg} . / 100 \mathrm{ml}$. in one hour.

Sweat electrolytes normal: $\mathrm{Na} 24 \mathrm{mEq} / \mathrm{l}$.; Cl 27 $\mathrm{mEq} / \mathrm{l}$; serum calcium $9.6 \mathrm{mg} . / 100 \mathrm{ml}$.; serum phosphorus $3.6 \mathrm{mg} . / 100 \mathrm{ml}$.; plasma alkaline phosphatase 22 K.A. units $/ 100 \mathrm{ml}$.; serum proteins 6.9 g. $/ 100 \mathrm{ml}$.; electrophoresis normal; jejunal mucosal biopsy (Dr. Margot Shiner) normal; fat absorption (four-day balance) on a normal diet, $61 \%$, after a fortnight on a gluten-free diet (four-day balance) it rose to $82 \%$, and a third estimation (four-day balance) commencing four days after resuming a normal diet showed $73 \%$ absorption.

In view of the oily nature of the stools, the good appetite, lack of abdominal distension, normal glucose tolerance and normal jejunal biopsy, it was considered that a diagnosis of coeliac disease could not be supported in spite of the improved fat absorption on a gluten-free diet. It was decided to give the boy a normal diet, and to treat him with pancreatin on the assumption that the oily stools were attributable to the low level of pancreatic lipase. Two tablets of Pancrex V Forte were given with each meal.

While on treatment, the stools appeared normal, and were not fatty, but after six months an attempt to reduce the dose of pancreatin led to the stools becoming loose and pale. A reduction to two tablets daily was followed by free oil in the stools.

After treatment for a year, three attempts to recover duodenal juice failed, but during the brief stay in hospital that this entailed, therapy was discontinued, and the stools remained normal. It had to be assumed that production of pancreatic lipase had improved. This proved correct, for on a normal diet and without pancreatin the stools remained normal and the boy continued to grow satisfactorily. A final six-day fat balance performed six months after cessation of treatment showed fat absorption to be $95 \%$.

\section{Comments on Case 5}

This boy was seen when Cases 1 and 2 were already known, but before Cases 3 and 4 had attended. His case has been added somewhat as a postscript, because the symptoms so closely paralleled those of the first two cases as to suggest that a deficiency of pancreatic lipase would be found on analysis of his duodenal juices. His history however makes it clear that his lipase deficiency was not a congenital disorder, but followed the illness of varicella. Unlike the previous cases, in which lack of pancreatic lipase has persisted, this boy's production of lipase eventually recovered after a year or so, and he has since remained normal.

It is difficult to avoid the conclusion that his condition was a direct sequel to varicella, but if this is so, such a complication does not appear to have been previously recorded. A personal inquiry of several medical superintendents of infectious fever hospitals showed that they had no knowledge of comparable cases. This complication, however, might well escape their detection if there were a lag period between varicella and subsequent steatorrhoea, for the stay in hospital of children with chicken-pox is relatively brief. The family doctor, treating varicella at home, is in the best position to detect a subsequent story of oily motions and soiling.

The encounter with Case 5 naturally led to the question of chicken-pox in relation to Cases 1 and 2, and it was of interest to learn that the mother of these children had had an unusually severe attack of varicella one month before she conceived Case 1 . It seems best simply to place this fact on record without further comment, for in the light of present knowledge it is difficult to draw any relation between her attack of chicken-pox and the subsequent appearance of lipase deficiency in her two children. It may be added that the mother of the second family (Cases 3 and 4) had an ordinary attack of varicella between her two pregnancies.

\section{Summary}

Two families, each consisting of two children, are recorded because all four children presented a similar clinical picture dominated by oily stools and soiling. The condition is regarded as congenital, and has proved to be persistent. It is very probably attributable to an autosomal recessive gene. Analysis of duodenal juice revealed a deficiency (and in one case absence) of pancreatic lipase. Production of trypsin and amylase also tended to be below normal values.

A fifth case is reported in which a similar clinical picture, associated with deficiency of pancreatic lipase, developed as a temporary phenomenon following an attack of chicken-pox.

\section{REFERENCES}

Bodian, M., Sheldon, W. and Lightwood, R. C. (1964). Congenital deficiency of the exocrine pancreas. Acta paediat. (Uppsala). In the press.

Farber, S., Shwachman, H. and Maddock, C. L. (1943). Pancreatic function and disease in early life. 1. Pancreatic enzyme activity and the celiac syndrome. J. clin. Invest., 22, 827.

Harrison, G. A. (1957). Chemical Methods in Clinical Medicine, 4th ed., p. 301. Churchill, London.

Horsfield, A. (1952). Proteolytic activity of stools. J. med. Lab. Technol., 10, 18.

Lowe, C. U. and May, C. D. (1951). Selective pancreatic deficiency. A.M.A. Amer. J. Dis. Child., 82, 459.

Sheldon, W. (1955). Coeliac disease. Lancet, 2, 1097.

Shwachman, H., Farber, S. and Maddock, C. L. (1943). Pancreatic function and disease in early life. III. Methods of analyzing pancreatic enzyme activity. Amer. J. Dis. Child., 66, 418.

Van Loon, E. J., Likins, M. R. and Seger, A. J. (1952). Photometric method for blood amylase by use of starch-iodine color. Amer. J. clin. Path., $22,1134$.

Young, N. F. (1953). Amylase. In Standard Methods of Clinical Chemistry, Vol. 1, p. 8. [American Association of Clinical Chemists] Academic Press, New York. 